\title{
THE LEGALITY OF THE „SHARE” IN THE BILLING OF THE PUBLIC WATER SUPPLY AND SEWAGE SERVICE
}

\author{
Liliana BELECCIU \\ Doctor of Law, Associate Professor, Academy „Ştefan cel Mare” of the Ministry \\ of Internal Affair, Chisinau, Republic of Moldova \\ email: lilianabelecciu@yahoo.com \\ https://orcid.org/0000-0003-4134-6983
}

The public water supply and sewerage service includes the totality of activities of public utility and general economic and social interest carried out for the purpose of the collection, treatment, transportation, storage and distribution of drinking water on the territory of the administrative-territorial unit, as well as for the purpose of the collection and purification of wastewater. This service is regulated, in particular, by the Law on public water supply and sewerage service No. 303/2013. The object of the law represents the creation of the legal framework for the establishment, organization, operation, regulation and monitoring of the public drinking water supply and sewerage service in the conditions of accessibility, availability, reliability, continuity, competitiveness, transparency, respecting quality, safety and environmental protection. Everything that exceeds these activities is not subject to the regulation of the Law No. 303/2013. And the application of the "share" is an illegal activity that is punishable in accordance with the legislation in force.

Keywords: public service, water, sewerage, share, environmental protection.

\section{LEGALITATEA «COTEI-PĂRȚI» ÎN FACTURAREA SERVICIULUI PUBLIC DE ALIMENTARE CU APĂ ŞI DE CANALIZARE}

Serviciul public de alimentare cu apă și de canalizare este un serviciu vital pentru populaţie (atât pentru persoanele fizice, cât şi cele juridice). Acesta cuprinde totalitatea activităţilor de utilitate publică şi de interes economic şi social general efectuate în scopul captării, tratării, transportului, înmagazinării şi distribuirii apei potabile pe teritoriul unităţii administrativ-teritoriale, precum şi în scopul colectării şi epurării apelor uzate. Serviciul este reglementat, în special, de Legea privind serviciul public de alimentare cu apă şi de canalizare nr. 303/2013. Obiectul legii reprezintă crearea cadrului legal pentru infiinţarea, organizarea, funcționarea, reglementarea şi monitorizarea serviciului public de alimentare cu apă potabilă şi de canalizare în condiţii de accesibilitate, disponibilitate, fiabilitate, continuitate, competitivitate, transparență, cu respectarea normelor de calitate, de securitate şi de protecție a mediului. Tot ce excede acestor activităţi, nu face obiectul de reglementare a Legii $n$ r. 303/2013. Iar aplicarea "cotei părţi”" este o activitate ilegală care se pedepseşte în conformitate cu legislaţia în vigoare.

Cuvinte-cheie: serviciu public, apă, canalizare, cotă-parte, protecţia mediului.

\section{LA LÉGALITÉ DE LA «QUOTE-PART» DANS LA FACTURATION DU SERVICE PUBLIC D'EAU ET D'ASSAINISSEMENT}

Le service public d'approvisionnement en eau et d'assainissement comprend toutes les activités d'utilité publique et d'intérêt économique et sociale générale effectuées aux fins de captage, de traitement, de transport, de stockage et de distribution de l'eau potable sur le territoire de l'unité administrative-territoriale, ainsi qu'aux fins de collecte et de l'épuration des eaux usées. Ce service est réglementé, notamment, par la Loi sur le service public d'approvisionnement en eau et d'assainissement no303/2013. L'objet de la Loi est la création du cadre juridique pour l'établissement, l'organisation, le fonctionnement, la réglementation et la surveillance du service public d'approvisionnement en eau potable et d'assainissement 
dans des conditions d'accessibilité, de disponibilité, de fiabilité, de continuité, de compétitivité, de transparence, en respectant les normes de qualité, de sécurité et de protection de l'environnement.Tout ce qui dépasse ces activités n'est pas soumis à la réglementation de la Loi $n^{\circ} 303 / 2013$. Et l'application de la «quote-part» est une activité illégale qui est punissable conformément à la législation en vigueur.

Mots-clés: Service public, l'eau, l'assainissement, la quote-part, la protection de l'environnement.

\section{ЗАКОННОСТЬ «ДОЛИ» В СЧЕТАХ ОБЩЕСТВЕННОЙ УСЛУГИ ВОДОСНАБЖЕНИЯ И КАНАЛИЗАЦИИ}

Служба общественного водоснабжения и канализации включает в себя все виды деятельности коммунального общеэкономического и сочиального значения, осуществляемые с иелью сбора, обработки, транспортировки, хранения и распределения питьевой воды на территории административно-территориальной единищы, а также для сбора и очистки сточных вод. Данная услуга регламентируется, в частности, Законом №. 303/2013 о коммунальном водоснабжении и канализации. Целью закона является создание правовой основы для образования, организации, функиионирования, регулирования и мониторинга коммунальных служб питьевого водоснабжения и канализации в условиях доступности, надежности, непрерывности, конкурентоспособности, прозрачности, соблюдения качества, безопасности и охраны окружающей среды. Все, что выходит за рамки перечисленных видов деятельности, не регламентируется Законом №. 303/2013. А применение «доли» - это незаконная деятельность, преследуемая согласно действующему законодательству.

Ключевые слова: коммунальная служба, вода, канализаџия, доля, охрана окружающей средыл.

\section{Introducere}

Ultima modificare a Legii privind serviciul public de alimentare cu apă şi de canalizare nr. 303/2013 a reprezentat o revizuire şi completare pe cât de inovativă, pe atât de necesară a cadrului legal care reglementează acest sector. Astfel, şi-a găsit reflectare în lege aspecte privind politica naţională de regionalizare a serviciului de alimentare cu apă şi de canalizare; regimul juridic al sistemelor publice de alimentare cu apă şi de canalizare; redevenţa achitată pentru transmiterea dreptului de folosință a bunurilor domeniului public/ privat al unității administrativ-teritoriale; tariful pentru producerea și/sau transportarea apei în vederea redistribuirii; Fondul de dezvoltare etc.

Prin aceeaşi lege, a fost modificat, inclusiv art. 29 alin. (2) din Legea 303/2013, care reglementează facturarea serviciului public de alimentare cu apă şi de canalizare în blocurile locative unde contractele de furnizare/prestare a serviciului sunt încheiate de operator cu administratorul blocului locativ.

Reglementările privind distribuirea diferenţei între volumul înregistrat de contorul de la branşamentul blocului locativ şi suma tuturor contoarelor instalate în apartamente, aşa numita "cota parte" au fost abrogate. Distribuirea pe apartamente a volumului de apă înregistrat de contorul de la branşamentul blocului locativ se va efectua în baza Regulamentului cu privire la prestarea serviciilor comunale și ne comunale, folosirea, exploatarea și administrarea locuințelor, care va fi aprobat de Guvern.

Temeiul acestei modificări are la bază obiectul de reglementare a Legii nr. 303/2013, şi anume activitatea de furnizare/prestare a serviciului public de alimentare cu apă şi de canalizare, prin intermediul sistemelor publice de alimentare cu apă şi de canalizare construite pe domeniul public al unităţii administrativ-teritoriale, până la limita de proprietate. Astfel, raporturile privind furnizarea/prestarea serviciului pe proprietatea privată exced cadrul legal al Legii nr. 303/2013.

În detrimentul acestor modificări, întreprinderile municipale de gestionare a fondului locativ au continuat calcularea şi încasarea "cotei-părţi” la facturarea serviciului de ali- 
mentare cu apă şi de canalizare în blocurile locative ${ }^{1}$.

Acest fapt poate fi dedus şi din numărul petiţiilor depuse la Agenţia pentru Protecţia Consumatorului şi Supravegherea Pieței. Autoritatea ne-a comunicat că dintre nemulțumirile consumatorilor privind furnizarea/prestarea serviciului de alimentare cu apă şi de canalizare, cel mai des semnalate se referă la «cota parte». Consumatorii îşi exprimă nemulţumirea privind achitarea acesteia, în contextul deţinerii unor contoare de apă verificate metrologic.

Metodologia de cercetare științifică folosită. In procesul de elaborare a studiului dat am folosit mai multe metode de cercetare ştiinţifică cum ar fi: cele generale (sau comune) și speciale. De remarcat faptul că cea mai mare parte a problemelor speciale ale științelor naturale și chiar unele etape de cercetare necesită utilizarea de metode speciale de soluționare. Din metodele generale de cercetare științifică am folosit:

1) metodele empirice de cercetare (observarea, comparația,);

2) metodele utilizate atât la nivel de cercetare empirică cât și teoretică (abstractizarea, analiza și sinteza, inducția și deducția, modelarea);

3) metodele teoretice de cercetare (ascensiunea de la abstract la concret).

\section{Particularitățile serviciului public de alimentare cu apă şi canalizare}

Întâmplător sau nu, în toamna anului 2020, un grup de deputaţi au înregistrat un proiect de lege cu privire la modificarea Legii privind serviciul public de alimentare cu apă și canalizare nr. 303/2013(iniţiativa legislativă nr. 462 din 24.11.2020). Potrivit notei informative, proiectul de lege a fost elaborat în scopul îmbunătăţirii reglementărilor relaţiilor dintre

\footnotetext{
${ }^{1}$ A se vedea în acest sens: https://anre.md/cota-parte-laapa-este-ilegala-gestionarii-risca-sa-fie-sanctionati-pentruexces-de-putere-sau-depasirea-atributiilor-de-serviciu-3-77
}

operator şi consumatorul serviciului public de alimentare cu apă şi de canalizare. În fundamentare se arată că la ora actuală, operatorii serviciului public de alimentare cu apă şi de canalizare practică încheierea contractului de furnizare/prestare a serviciului public cu administratorii blocurilor locative, iar facturarea are loc în baza indicilor contorului comun instalat la branşamentul blocului. Toate acestea în condiţiile în care consumatorii finali au instalate contoare individuale, verificate metrologic conform cerinţelor prevăzute de Legea metrologiei nr. 19/2016.

Deşi în partea finală a notei informative este specificat că modificările propuse vor asigura respectarea drepturilor consumatorilor persoane fizice şi vor diminua abuzurile ce pot veni din partea administratorilor blocurilor locative, autorii proiectului de lege nu sesizează că acestea sunt raporturi de drept privat, reglementate prin alte acte normative, nicidecum prin Legea nr. 303/2013.

Pentru o mai bună înţelegere a modului de organizare şi funcţionare a serviciului public de alimentare cu apă şi de canalizare, a dreptului şi obligaţiei operatorului de a furniza/ presta acest serviciu vital, în continuare vom prezenta cele mai importante reglementări legale stabilite în Legea privind serviciul public de alimentare cu apă şi de canalizare nr. 303/2013.

Potrivit art. 3 alin. (1) din Legea nr. $303 / 2013$, serviciul public de alimentare cu apă și de canalizare cuprinde totalitatea activităţilor de utilitate publică şi de interes economic şi social general efectuate în scopul captării, tratării, transportului, înmagazinării şi distribuirii apei potabile sau tehnologice la toţi consumatorii de pe teritoriul unei sau al mai multor localităţi, precum şi în scopul colectării, transportului, epurării şi evacuării apelor uzate.

Menţionăm că serviciul public de alimentare cu apă și de canalizare face parte din sfera serviciilor publice de gospodărie comunală 
organizate la nivelul unităților administrativteritoriale, care are drept scop asigurarea alimentării cu apă, canalizarea și epurarea apelor uzate pentru toți consumatorii de pe teritoriul localităţii.

Acest serviciu public are 2 componente:

a) serviciul public de alimentare cu apă, reprezentând totalitatea activităţilor necesare pentru: captarea apei brute din surse de suprafață sau subterane; tratarea apei brute; transportarea apei potabile şi/sau tehnologice; înmagazinarea apei; distribuţia apei potabile şi/ sau tehnologice;

b) serviciul public de canalizare, reprezentând totalitatea activităţilor necesare pentru: colectarea, transportarea şi evacuarea apelor uzate de la consumatori la staţiile de epurare; epurarea apelor uzate şi evacuarea apei epurate în emisar.

În Republica Moldova aceste 2 componente ale serviciul public de alimentare cu apă și de canalizare sunt asigurate de către un singur operator(este cazul a peste $80 \%$ din operatorii apă-canal). Însă, este posibilă și separarea acestora, existând operatori care vor furniza doar serviciul public de alimentare cu apă(spre exemplu: Întreprinderea Municipală «Apă-canal Bălți»; operatorii din comune și sate unde este organizat doar serviciul de alimentare cu apă), operatori care vor presta doar serviciul public de canalizare(spre exemplu, SRL «GLORIN Engeneering» Bălți), operatori care vor asigura doar anumite activități din cadrul acestor servicii(spre exemplu, Întreprinderea de Stat «Acva-Nord» care asigură doar captarea apei brute, tratarea și transportarea apei potabile).

În temeiul principiilor constituţionale ${ }^{2}$ - autonomiei locale şi descentralizării serviciilor publice - competenţa privind înfiinţarea serviciului public de alimentare cu apă şi de canalizare aparţine autorităţilor publice locale. Astfel, autoritățile deliberative(consiliile locale/

\footnotetext{
${ }^{2}$ Constituţia Republicii Moldova adoptată la 29.07.1994, publicată în Monitorul Oficial al Republicii Moldova nr. 1 din 12.08.1994.
}

consiliile orășenești) ale unităților administrativ-teritoriale au competența exclusivă privind înfiinţarea, organizarea, coordonarea, monitorizarea şi controlul funcţionării serviciilor publice de alimentare cu apă și de canalizare, precum şi crearea, administrarea şi exploatarea bunurilor proprietate publică din infrastructura tehnico-edilitară a unităţilor administrativteritoriale aferente acestui serviciu ${ }^{3}$.

În cazul constatării unor necesităţi imperioase în asigurarea acestui serviciu vital la nivelul unităţii administrativ-teritoriale, autoritatea publică locală va demara procedura privind înfiinţarea acestuia. La organizarea, funcţionarea şi dezvoltarea serviciului public de alimentare cu apă și de canalizare, interesul general al localităților și al cetățenilor este prioritar.

Serviciul public de alimentare cu apă şi de canalizare se furnizează/prestează prin crearea şi exploatarea unei infrastructuri tehnico-edilitare specifice, denumită sistem public de ali-

\footnotetext{
${ }^{3}$ Principalele competențe ale autorităților publice locale, statuate în art. 8 alin. (1) din Legea nr. 303 din 13.12.2013 sunt:

- aprobarea elaborarea şi implementarea planurilor proprii de dezvoltare şi de funcţionare, pe termen scurt, mediu şi lung, a serviciului public de alimentare cu apă şi de canalizare în conformitate cu planurile urbanistice generale, cu programele de dezvoltare social-economică a unităţii administrativ-teritoriale, precum şi potrivit angajamentelor internaţionale în domeniul de protecţie a mediului;

- înfiinţarea, organizarea, coordonarea, monitorizarea şi controlul funcţionării serviciului public de alimentare cu apă si de canalizare;

- aprobarea tarifelor la serviciul public de alimentare cu apă potabilă şi de canalizare şi pentru serviciile auxiliare furnizate de către operatori consumatorilor, calculate în conformitate cu metodologiile elaborate şi aprobate de către Agenţie;

- administrarea sistemului public de alimentare cu apă şi de canalizare ca parte a infrastructurii tehnico-edilitare a unităţilor administrativ-teritoriale respective;

- delegarea gestiunii serviciului public de alimentare cu apă şi de canalizare şi a bunurilor publice corespunzătoare conform legislaţiei în vigoare;

- contractarea sau garantarea, în condiţiile legii, a împrumuturilor pentru finanțarea programelor de investiții în vederea dezvoltării sistemului public de alimentare cu apă şi de canalizare a localităţilor, pentru efectuarea de lucrări noi sau de extinderi, pentru dezvoltarea de capacităţi, inclusiv pentru reabilitarea, modernizarea și reechiparea sistemelor existente;

- asigură alimentarea cu apă, precum şi serviciul de canalizare în situații excepţionale; etc.
} 
mentare cu apă şi de canalizare. Doar în cazul existenţei/demarării activităţilor privind construcţia acestor sisteme, autoritatea publică locală poate înfiinţa serviciul de alimentare cu apă şi de canalizare.

Sistemele publice de alimentare cu apă și de canalizare, statuează art. $13^{1}$ alin. (1) din Legea nr. 303/2013, sunt parte componentă a infrastructurii tehnico-edilitare a unităților administrativ-teritoriale, sunt bunuri de interes și folosință publică și aparțin, prin natura lor sau potrivit legii, domeniului public al unităților administrativ-teritoriale. Aceste bunuri au un regim juridic distinct - fiind inalienabile, imprescriptibile și insesizabile, nu pot fi depuse ca aport la capitalul societăților comerciale (inclusiv cele înființate de autoritățile administrației publice locale și centrale) și nu pot constitui garanții pentru creditele bancare contractate de autorităţile administrației publice locale sau de operatori.

Sistemele de alimentare cu apă și de canalizare sunt construite pe terenul public al localității, respectiv aparțin domeniului public al acestora, competența de administrare revenind autorităților deliberative(consiliile locale/consiliile orășenești). În cazul finanţării de către persoane fizice sau juridice de drept privat, alte entități, sistemele de alimentare cu apă și de canalizare vor fi transmise în proprietatea unităţilor administrativ-teritoriale în 2 moduri: fie gratuit, fie contra cost, în una din modalităţile de transmitere în proprietate, reglementate de legislația în vigoare ${ }^{4}$.

${ }^{4}$ Potrivit art. 19 alin. (4) din Legea nr. 303 din 13.12.2013, la finalizarea lucrărilor de construcţie, instalaţiile şi reţelele publice de alimentare cu apă şi de canalizare, situate pe teren public, construite de persoane fizice şi/sau de persoane juridice, indiferent de sursa de finanţare, se transmit autorităţii administraţiei publice locale sau direct operatorului în conformitate cu decizia consiliului local.

Potrivit acestei prevederi, toate bunurile finantate sau construite de cetăţeni, agenți economici pe teren public, se transmit în proprietatea autorităţii administraţiei publice locale sau direct operatorului.

Pentru început atragem atenţia asupra unui aspect, care poate crea grave încălcări ale legislației, în ceea ce privește regimul juridic al proprietății publice. Potrivit art. $13^{1}$ din Legea nr. 303 din 13.12.2013, infrastructura de alimentare cu apă și de canalizare până la punctul de delimitare aparține
Prin urmare, aceste bunuri sunt și rămân proprietatea unitătii administrativ-teritoriale, neputând fi vândute sau privatizate, neputând fi sechestrate pentru datoriile operatorului sau a unităţii administrativ-teritoriale etc.

Dacă înfiinţarea şi organizarea serviciului de alimentare cu apă şi de canalizare aparţine exclusiv autorităţilor publice locale, atunci gestiunea poate fi organizată în două modalități: gestiune directăşi gestiune delegată.

Modalitatea de gestiune se stabilește prin decizii ale autorităților deliberative ale unităților administrativ-teritoriale, în funcție de: natura și starea serviciului; necesitatea asigurării celui mai bun raport preț/calitate; interesele actuale și de perspectivă ale unităților administrativ-te-

domeniului public al unităţii administrativ-teritoriale. Prin urmare, bunurile aferente serviciului de alimentare cu apă şi de canalizare construite pe domeniul public trebuie transmise în proprietatea unității administrativ-teritoriale. Ulterior, autoritatea publică locală va transmite aceste bunuri în gestiune operatorilor.

În acest context, se recomandă, transmiterea bunurilor construite pe teren public de către persoane fizice şi/sau juridice să se facă în proprietatea autorităților publice locale, nicidecum în proprietatea operatorilor.

De asemenea, menționăm că, inițial, acest articol prevedea și modul de transmitere, anume cu titlu gratuit, fără vreo recompensă din partea administrației publice sau de la operator. Însă, prin Hotărârea Curții Constituționale nr. 30 din 01.11.2016, sintagma „gratuit la balanța” a fost declarată neconstituțională.

În prezent, în Parlamentul Republicii Moldova este în examinare proiectul de lege pentru modificarea și completarea unor acte legislative nr. 256 din 25.07.2017, care va clarifica anumite aspecte privind modul de transmitere în proprietate către autoritățile publice locale a bunurilor construite de cetățeni, agenți economici etc.

Astfel, art. 19 alin. (4) se propune a fi modificat și completat cu alin. $\left(4^{1}\right)$ după cum urmează:

(4) "Bunurile finanțate şi/sau construite de persoane fizice și/sau juridice pe teren public, reprezentând sisteme publice de alimentare $\mathrm{cu}$ apă și de canalizare, se transmit în proprietatea unității administrativ-teritoriale, în temeiul unui act juridic reglementat de legislația în vigoare."

(4)"Bunurile pot fi transmisecu titlu gratuit sau cu titlu oneros, in funcție de modalitatea de transmitere convenită intre părți. In cazul transmiterii cu titlu oneros, recompensarea se va face la valoarea reală a bunurilor, demonstrată prin acte justificative, fiind stabilită prin acordul părților sau prin hotărârea instanței de judecată. Până la transmiterea bunurilor în proprietatea unității administrativ-teritoriale sau demararea acestor proceduri prin semnarea actelor juridice corespunzătoare, operatorul nu are dreptul să furnizezel presteze serviciul public de alimentare cu apă și de canalizare prin aceste bunuri." 
ritoriale; mărimea și complexitatea sistemelor de alimentare cu apă și de canalizare.

În cadrul gestiunii directe, autorităţile administraţiei publice locale îşi asumă nemijlocit toate sarcinile şi responsabilităţile privind organizarea şi funcţionarea serviciului public de alimentare cu apă şi de canalizare. Gestiunea directă se realizează prin intermediul unor structuri ale autorităților administrației publice locale, care pot fi:

a) compartimente de specialitate, fără personalitate juridică, organizate în cadrul aparatului propriu al consiliului local al unității administrativ-teritoriale;

b) entități specializate, cu personalitate juridică, organizate în subordinea consiliului local al unității administrativ-teritoriale, având patrimoniu propriu, gestiune economică proprie și autonomie financiară și funcțională.

$\mathrm{Cu}$ referinţă la gestiunea delegată, - este modalitatea de management prin care o unitate administrativ-teritorială atribuie unuia sau mai multor operatori, dreptul de furnizare/prestare a serviciului sau a unei componente a acestuia, în baza unui contract de delegare a gestiunii ${ }^{5}$. Delegarea gestiunii serviciului implică operarea propriu-zisă a serviciului, concesionarea

\footnotetext{
5 Contractul de delegare a gestiunii serviciilor este documentul, încheiat în formă scrisă, prin care unitățile administrativ-teritoriale atribuie, pe o perioadă determinată, unui operator/unor operatori, care acționează pe riscul și răspunderea proprie, dreptul și obligația de a furniza / presta serviciul public de alimentare cu apă şi de canalizare, integral sau, după caz, numai unele activități specifice acestuia, inclusiv dreptul şi obligaţia de a administra şi de a exploata infrastructura tehnico-edilitară $\neg \neg$ aferentă serviciului furnizat/prestat sau activităţii efectuate, în schimbul unei redevenţe. Din momentul intrării în vigoare, contractul de delegare a gestiunii serviciului devine obligatoriu pentru părțile semnatare.

Obiectul contractului de delegare a gestiunii serviciului public de alimentare cu apă și de canalizare îl constituie: dreptul exclusiv de a furniza/presta serviciile publice de alimentare cu apă și de canalizare în cadrul ariei de competență teritorială a autorității publice; dreptul exclusiv de a exploata, întreține și administra bunurile delegate, precum şi investițiile privind reabilitarea și dezvoltarea acestora.

Astfel, contractul de delegare a gestiunii este principalul document între părțile semnatare, unde sunt enumerate drepturile și obligațiile autorității publice locale, pe de o parte, și ale operatorului, pe de altă parte, privind organizarea și funcționarea serviciului public de alimentare cu apă și de canalizare.
}

sistemului public aferent serviciului delegat, precum și dreptul și obligația operatorului de a administra și de a exploata sistemul respectiv.

Conform art. 13 alin. (2) din Legea nr. 303 din 13.12.2013, procedurile de atribuire a contractelor de delegare a gestiunii sunt licitația publică și negocierea directă, organizate în baza Procedurii-cadru privind organizarea, derularea și atribuirea contractelor de delegare a gestiunii serviciului public de alimentare cu apă şi de canalizare, aprobată de Guvern.

Indiferent de modalitatea de gestiune aleasă, autorităţile publice locale prin decizia privind darea în administrare (gestiune directă)/decizia privind atribuirea şi încheierea contractelor de delegare a gestiunii serviciului(gestiunea delegată) abilitează operatorul să furnizeze/presteze serviciul public de alimentare cu apă şi de canalizare pe teritoriul unităţii administrativ-teritoriale. Astfel, operatorul are dreptul şi obligaţia să asigure serviciul prin intermediul sistemelor publice de alimentare cu apă şi de canalizare pe raza de competenţă a autorităţii publice locale, adică până la limita de proprietate public/privat.

Autoritatea publică locală nu deţine competenţe privind furnizarea/prestarea serviciului public de alimentare cu apă şi de canalizare pe proprietatea privată a consumatorilor.

Această limită este stabilită prin punctul de delimitare, reprezentând acel loc în care instalaţia interioară de apă şi/sau de canalizare a consumatorului se conectează la sistemul public de alimentare cu apă şi/sau de canalizare. La casele de locuit individuale, punctul de delimitare se stabileşte la ieşirea din contorul instalat în căminul de branşare, amplasat în limita teritoriului consumatorului. La blocurile locative, punctul de delimitare se stabileşte la ieşirea din contorul instalat în subsolul blocului locativ. Pentru reţelele de canalizare, punctul de delimitare este căminul de racord la reţeaua publică în sensul de scurgere a apei uzate.

După punctul de delimitare, consumatorul este responsabil de întreţinerea reţelelor interioare de apă/canalizare, respectiv de calitatea servi- 
ciului dat. Fiind vorba de proprietatea privată a consumatorilor, aceste aspecte sunt reglementate de normele dreptului de proprietate privată.

Dacă în cazul caselor de locuit totul este clar, atunci apar foarte multe întrebări privind asigurarea serviciului de alimentare cu apă şi de canalizare în cadrul blocurilor locative. La clădirile cu mai multe etaje sau apartamente, pe lângă spaţiile locative, există anumite părţi din clădire, care nu pot fi folosite decât în comun, reprezentând proprietatea comună a tuturor locatarilor. Dacă prin lege sau prin act juridic nu se prevede altfel, sunt asemenea părţi comune, terenul pe care se află clădirea, acoperişul, terasele, scările şi casa scărilor, holurile, subsolul, ascensoarele, instalaţiile de apă şi canalizare, electrice, de telecomunicaţii, de încălzire şi de gaze, alte asemenea părţi şi alte bunuri care, potrivit legii sau voinţei părţilor sunt de folosinţă comună.

Caracteristic proprietăţii comune este faptul că părţile comune aparţin simultan și concomitent tuturor proprietarilor, fiecare dintre aceștia având numai o cotă-parte ideală şi abstractă, fără ca bunurile să fie fracționate efectiv.

În temeiul acestui drept, coproprietarii au obligaţia să suporte cheltuielile de întreţinere, folosinţă, reparaţii, conservare a părţilor comune din blocul locativ proporţional cu cotaparte din drept care revine fiecăruia.

Raporturile care se stabilesc între coproprietari privind proprietatea comună pe cote-părţi, modul de întreţinere şi exploatare a părţilor comune precum şi modul de furnizare/prestare a serviciilor publice în interiorul condominiului fac obiectul de reglementare a Legii condominiului în fondul locativ nr. 913/2000.

Revenind la serviciul de alimentare cu apă şi de canalizare, potrivit art. 4 alin. (3) din Legea nr. 913/2000, punctele de delimitare a instalaţiilor interne din condominiu şi a reţelelor publice sunt:

a) la reţelele de alimentare cu apă - ieşirea din contorul instalat în subsolul blocului locativ conform avizului de branşare eliberat de către operatorul de serviciu; b) la reţelele de canalizare - căminul de racord la reţeaua publică în sensul de scurgere a apei uzate.

Prin urmare, raporturile privind furnizarea/ prestarea serviciului de alimentare cu apă şi de canalizare în interiorul blocului locativ, după punctul de delimitare, trebuie să fie punctate în Legea nr. 913/2000 şi desfăşurate într-un Regulament aprobat prin Hotărâre de Guvern.

\section{Concluzii}

Serviciul public de alimentare cu apă și de canalizare cuprinde totalitatea activităţilor de utilitate publică şi de interes economic şi social general efectuate în scopul captării, tratării, transportului, înmagazinării şi distribuirii apei potabile pe teritoriul unităţii administrativ-teritoriale, precum şi în scopul colectării şi epurării apelor uzate. Acest serviciu este reglementat, în special, de Legea privind serviciul public de alimentare cu apă şi de canalizare nr. 303/2013. Obiectul legii reprezintă crearea cadrului legal pentru înfiinţarea, organizarea, funcţionarea, reglementarea şi monitorizarea serviciului public de alimentare cu apă potabilă şi de canalizare în condiţii de accesibilitate, disponibilitate, fiabilitate, continuitate, competitivitate, transparenţă, cu respectarea normelor de calitate, de securitate şi de protecţie a mediului. Tot ce excede acestor activităţi, nu face obiectul de reglementare a Legii nr. 303/2013. Iar aplicarea "coteipărţi” este o activitate ilegală care se pedepseşte în conformitate cu legislaţia în vigoare.

\section{Bibliografie}

1. Constituţia Republicii Moldova adoptată la 29.07.1994, publicată în Monitorul Oficial al Republicii Moldova nr. 1 din 12.08.1994.

2. Legea privind serviciul public de alimentare cu apă şi de canalizare nr. 303/2013, publicată în Monitorul Oficial al Republicii Moldova Nr. 60-65 art. 123 din 14-03-2014

3. https://anre.md/cota-parte-la-apa-este-ilegala-gestionarii-risca-sa-fie-sanctionati-pentruexces-de-putere-sau-depasirea-atributiilor-deserviciu-3-77. 